\title{
Remdesivir: Mechanism and Effectiveness for Coronavirus Disease 2019 (COVID-19)
}

\author{
Vina Neldi, Suharjono* \\ Faculty of Pharmacy, Universitas Airlangga, Surabaya, Indonesia
}

\begin{abstract}
Currently, coronavirus disease 2019 (COVID-19) is a very serious health problem. The World Health Organization (WHO) has characterized this disease as a pandemic. Recommendations related to vaccines and drugs are not available yet because they are still in the clinical trial phase, and one of the superior drugs is remdesivir which has an antiviral activity. Several clinical trials of this drug are being carried out with the aim of evaluating its safety and efficacy in COVID-19 patients. There are two clinical trials with completed recruitment status, which are NCT04257656 and NCT04280705. NCT04257656 showed that remdesivir had faster time for clinical improvement in severe COVID-19 patients compared to placebo although it was not found to be statistically significant. Moreover, NCT04280705 showed that remdesivir was superior compared to placebo in shortening the recovery time in hospitalized adults with COVID-19. Gilead Sciences is also conducting clinical trials on this drug, and WHO has also conducted a solidarity trial and INSERM DisCoVery trials on remdesivir. Based on two clinical trials completed, satisfactory results are shown in patients with remdesivir therapy compared with patients who received placebo, although it is very important to wait for the results of other ongoing clinical trials to strengthen the evidence of the safety and efficacy of this drug.
\end{abstract}

Keywords: COVID-19; SARS-CoV-2; remdesivir; mechanism of action; clinical trial

*corresponding author

Email: suharjono@ff.unairac.id

\section{INTRODUCTION}

Currently, coronavirus disease 2019 (COVID-19) brings a critical conundrum to public health worldwide. The virus spreads so rapidly. It first appeared on December 31st, 2019, which was reported by Wuhan Health Commission in Hubei Province of the Republic of China. There have been reports about some cases of pneumonia with an unclear etiology; these patients showed symptoms such as fever and dry cough. The radiologist confirmed that there are bilateral lung glassy opacities (Kakodkar et al., 2020). On January 7th, 2020, The Chinese Center for Disease Control and Prevention (CDC) named the virus as novel coronavirus 2019 (2019$\mathrm{nCoV}$ ) which ultimately causes COVID-19 (Ahsan et al., 2020; Kakodkar et al., 2020; Xu J et al., 2020). Based on the geographic location in which the virus was spread, and the symptom showed by the patients, WHO renamed it to severe acute respiratory syndrome coronavirus 2 (SARS-CoV-2). On March 11th, 2020, WHO declared COVID-19 as a pandemic due to the expansion of this virus worldwide that raised significantly (Ahsan et al., 2020; Benvenuto et al., 2020; Kakodkar et al., 2020).

The World Health Organization (WHO) has recommended several preventive strategies that can be taken to prevent the spread of this virus, such as laboratory testing for individuals suspected of being infected with this virus, quarantine for infected patients, physical distancing and hand hygiene (WHO, 2020). Although preventive strategies have been carried out, there are no vaccine or drug recommendations that have been approved as prophylaxis or treatment for COVID-19. At present, there are several classes of drugs that are in the clinical trial stage related to their potential in combatting SARS$\mathrm{CoV}-2$ such as RNA polymerase inhibitors (remdesivir and favipiravir), protease inhibitors (lopinavir/ritonavir), aminoquinolines (chloroquine and their hydroxyl derivatives), anti-inflammatory agents (corticosteroids, Jianping injection), angiotensin-converting enzyme type 2 blockers, convalescent plasma, Viral RNA antisense technologies, monoclonal antibodies and Chinese traditional medicine (http://www.chictr.org.cn/index. aspx and http://clinicaltrials.gov/ct2/home).

Remdesivir is an antiviral that is one of the superior drugs in clinical testing. This drug shows the effectiveness as antiviral as it has a broad spectrum of coronaviruses that infect humans and animals in cell culture and experiments using mice, including SARS-CoV, MERS-CoV, and SARS-CoV-2 (Li et al., 2020). Besides, in several case reports, COVID-19 patients also showed recovery after being administered with remdesivir without showing any side effects. Therefore, this review aims to provide a review relating to viral polymerase inhibitors, especially remdesivir as a potential therapeutic option 
for COVID-19, and to summarize the evidence of the antiviral effect of remdesivir on COVID-19.

\section{OVERVIEW}

\section{SARS-CoV-2}

SARS-CoV-2 belongs to $\beta$-Coronavirus family with a single-stranded RNA that has envelopes with a diameter of 50-200 nm. This virus has a genomic RNA of 30 $\mathrm{Kb}$ with spike glycoprotein (S) consisting of S1-S2 heterodimers (Figure 1) (Kakodkar et al., 2020). The S protein is the receptor binding site capable of binding to angiotensin-converting enzyme 2 (ACE2) receptors in type II pneumocytes (Song et al., 2018; Xu X et al., 2020). This virus enters type II pneumocyte through endocytosis, and proliferates in the cytoplasm. The RNA from SARS-CoV-2 which acts as a pathogen-associated molecular pattern (PAMP) will be recognized by the pattern recognition receptor which causes a chemokine surge; this condition leads to migration and activation of neutrophils, resulting in damaged alveolar capillary walls (Figure 2) (Kakodkar et al., 2020; Ahmad et al., 2020). At present, the pathogenesis of COVID-19, which leads to disruption in the respiratory tract, remains unclear. Based on the pathological autopsy performed on COVID-19 patients, it was shown that alveolar damage and pulmonary hyaline membrane formation occur in the patients' lung. This situation leads to a condition of acute respiratory distress syndrome (ARDS).

Based on flow cytometry, the number of CD4+ and $\mathrm{CD} 8+\mathrm{T}$ lymphocytes in peripheral blood was decreased, but their activities became overactive. Furthermore, CCR4+ and CCR6+ Th17 lymphocytes, which have high proinflammatory effects, increased in CD4+ $\mathrm{T}$ lymphocytes. CD8+ $\mathrm{T}$ lymphocytes have cytotoxic granules with high concentrations of $31.6 \%$ positive perforins, $64.2 \%$ positive lysine particles, and $30.5 \%$ positive perforins and lysine particles. This condition shows that severe immune injury in patients is closely related to the improvement of the reactive $T$ lymphocytes, which is characterized by an increase of Th17 lymphocytes and an increase in cytotoxicity from CD8+ T lymphocytes (Cao et al., 2020; Xu Z et al., 2020).

\section{Remdesivir}

\section{Structure and mechanism of action}

Remdesivir is one of the most widely studied antivirals for COVID-19 therapy. This is related to the possibility of the effectiveness of remdesivir against SARS-CoV-2. An in vitro study showed that remdesivir has an activity in inhibiting SARS and MERS viruses which are other types of coronaviruses (Ahsan et al., 2020; Cao et al., 2020). Therefore, theoretically it is estimated that this drug also has an effect on COVID-19 (Cao et al., 2020). Remdesivir (GS-5734TM) is a monophosphoramidate prodrug derived from Pyrrolo [2,1-fl [triazin-4-amino] adenine C-nucleoside (Figure 3) (Sisay, 2020; Yavuz \& Unal, 2020). This drug is a broad-spectrum antiviral (tested using cell culture, mice and nonhuman primate models) (Sheahan et al., 2017; Lo et al., 2019; De et al., 2020; Wang et al., 2020: Yavuz \& Unal, 2020). Its antiviral activity is demonstrated by single stranded RNA viruses which is more effective if given at an early stage of infection when the virus starts to multiply in the upper respiratory tract (Figure 4) (Agostini et al., 2018; Yavuz \& Unal, 2020).

Remdesivir is metabolized into an active form namely adenosine triphosphate analog which has an activity

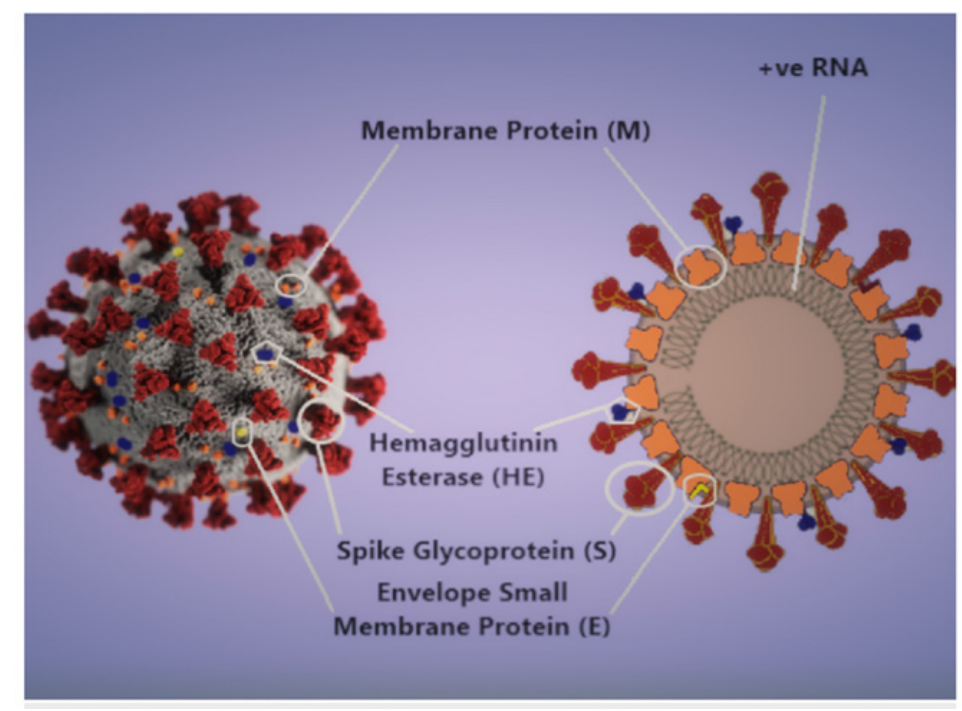

Figure 1. Structure of SARS-CoV-2, the virus that causes Coronavirus Disease 2019 (COVID-19) (Kakodkar et al., 2020) 


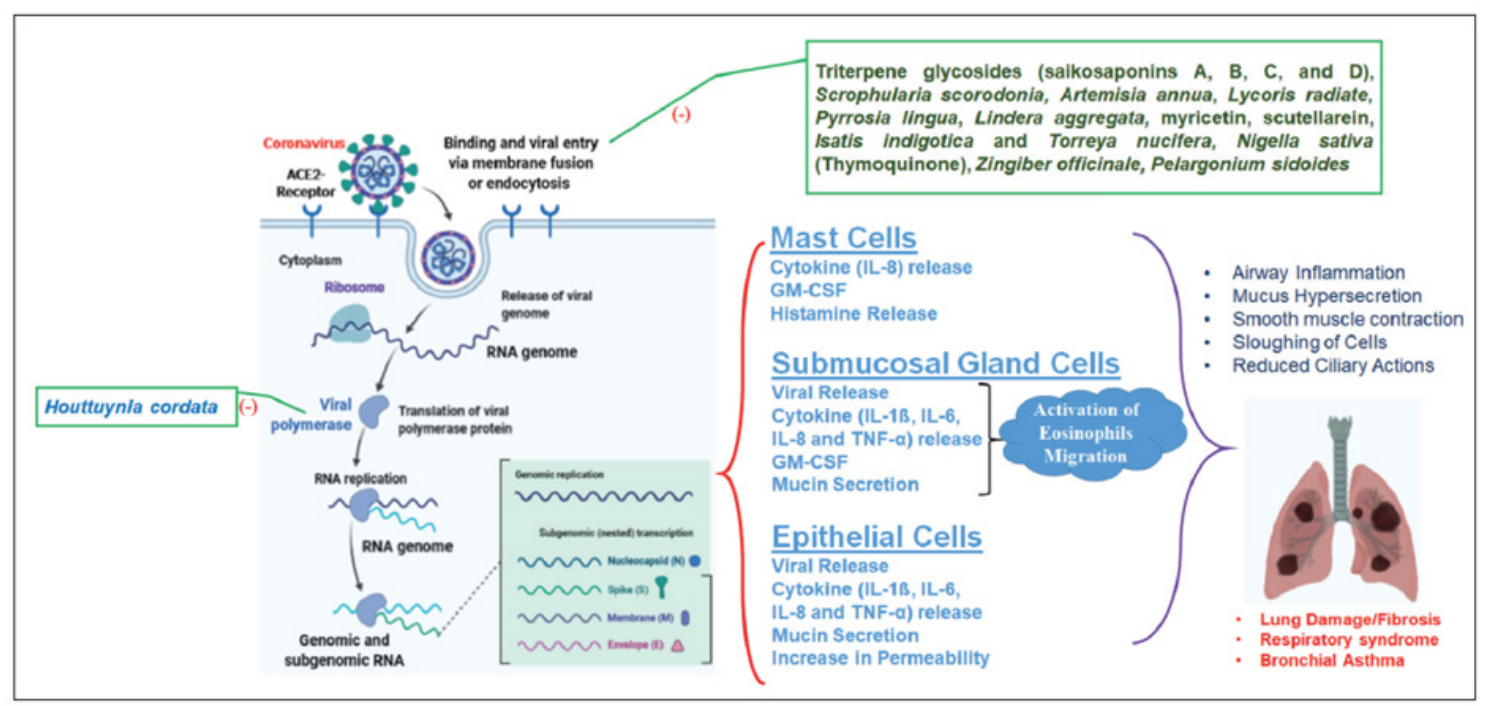

Figure 2. Mechanism of Severe Acute Respiratory Syndrome Coronavirus 2 (SARS-CoV-2) that leads to pulmonary destruction (Ahmad et al., 2020)

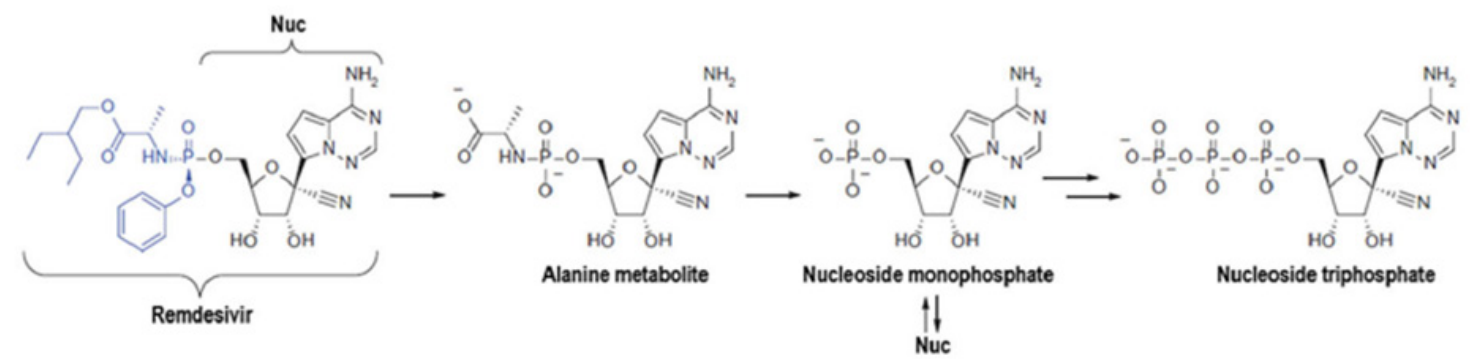

Figure 3. Remdesivir (GS-5734) and its active metabolite (GS-443902) (Sisay, 2020)

that inhibits RNA-dependent RNA Polymerase (RdRp) thus causing proofreading by the virus exonuclease to disrupt and stop the process of RNA synthesis (Cao et al., 2020; Sisay, 2020; Yavuz \& Unal, 2020). RdRp is a protein that has an important role in the replication of coronaviruses in epithelial cells of the respiratory tract (Cao et al., 2020; Yavuz \& Unal, 2020). The effect of remdesivir is supposed to be related to the activity of this drug which is capable of disrupting nsp 12 polymerase in proofreading exoribonuclease. In addition, remdesivir efficiently shows the active pharmacological effect of nucleoside triphosphate (NTP) which acts as an alternative substrate and RNA terminator chain. NTP is able to inhibit coronavirus by inserting active triphosphate into the viral RNA. In research carried out by molecular dynamics simulation and free energy perturbation method, it was also shown that RdRp is the target of remdesivir in SARS-CoV-2 virus (Zhang and Zhou, 2020). In addition, studies conducted on MERS$\mathrm{CoV}$ virus by Gordon et al., showed the same results in which RdRp was the target of this drug (Gordon et al., 2020).

\section{Pharmacokinetics}

Remdesivir demonstrated potential therapeutic effect for SARS-CoV-2 with EC50 for 48 hours of $0.77 \mu \mathrm{M}$ in vero cells E6 (Wang et al., 2020). Similar activity was also seen in other zoonotic coronaviruses with EC50 values of $0.07 \mu \mathrm{M}$ for SARS-CoV-1 and MERS-CoV (Sheahan et al., 2017; Gordon et al., 2020; Wang et al., 2020). The results of a preclinical in vitro study indicate that remdesivir/chloroquine provides high effectiveness in controlling infections due to SARS-CoV-2 (Wang M et al., 2020). In the research aiming to observe the effects of remdesivir as a preventive treatment using mice that had been infected with SARS, the results were shown to be satisfactory. Administration of remdesivir on the first day after the mice were induced by the disease showed a significant reduction in lung virus titers and showed improvement in the lung function of mice. On the other hand, administration of the drug on the second days after the mice were induced by the disease showed a significant reduction of the virus titer in the lungs but the survival rate of the mice was still relatively low. From these experiments it can be concluded that when the lung 


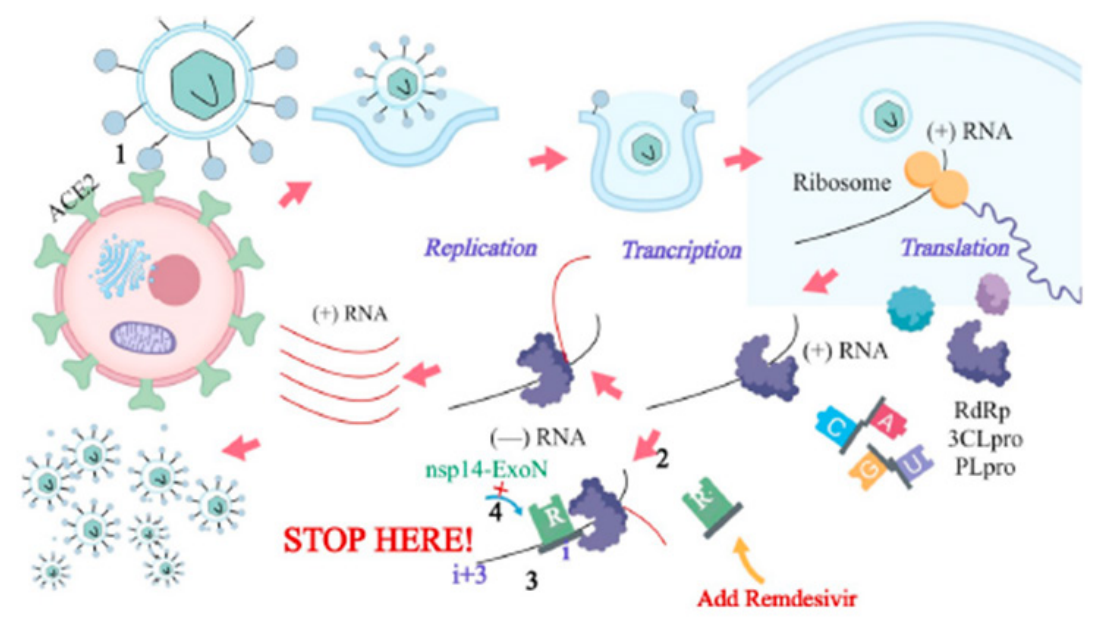

Figure 4. Mechanism of SARS-CoV-2 as an RNA virus and mechanism of action of remdesivir in inhibiting the virus (Cao et al., 2020)

injuries got maximum condition, a simple reduction of the virus titer cannot prolong the suppression of the immune response to the mice strongly (Sheahan et al., 2020).

Pharmacokinetic testing conducted on cynomolgus monkeys demonstrated the first-pass effect of oral remdesivir which causes the value of bioavailability to be low. Administration of this drug by intramuscular injection with a dose of $3 \mathrm{mg} / \mathrm{kg}$ showed a survival rate of $50 \%$ compared to the control group. Meanwhile, the intravenous administration at a dose of $10 \mathrm{mg} / \mathrm{kg}$ in a cynomolgus monkey demonstrated that this drug rapidly turns into the active metabolite (nucleoside phosphate). After 2 hours of administration, remdesivir was distributed into peripheral blood mononuclear cells (PBMC) and changed into the active forms to reach peak levels with a survival rate of $100 \%$ (Warren et al., 2015). After remdesivir is given intravenously, it will enter cells and will be metabolized into the active form which is GS-443902. Its exposure to PBMC demonstrated that the half-life of remdesivir active form is more than 35 hours. An experiment showed that the active form of remdesivir will accumulate in vivo. This led to a large-scale clinical trial after the administration of remdesivir with the first dose of $200 \mathrm{mg}$ carried out by administering the dose to $100 \mathrm{mg}$ for the next dose with the aim to maintain drug concentration in the blood (Mulangu et al., 2019).

Other pharmacokinetic in vivo studies of remdesivir showed that the administration of a single dose of remdesivir solution formulation over a dose range of 3-225 mg intravenously for 2 hours showed the linear pharmacokinetic profile of this drug. An intravenous infusion with a dose of $150 \mathrm{mg}$ repeated for 1 hour per day shows a linear pharmacokinetic profile for more than 14 days. Intravenous injections of remdesivir with doses of $75 \mathrm{mg}$ and $150 \mathrm{mg}$ for more than 2 hours also showed a pharmacokinetic profile that is almost the same as the lyophilized form. In addition, an intravenous infusion with a dose of $75 \mathrm{mg}$ for more than 30 minutes showed that the drug exposure is almost the same as the parent drug if given at the same dose for 2 hours (Cao et al., 2020).

\section{Clinical trials of remdesivir}

The first case report of remdesivir treatment as an antivirus came from the United States. This drug was first given to a 35-year-old male patient in Snohomish, Washington. This patient received remdesivir therapy on the seventh day after being hospitalized (eleventh day of illness) due to pneumonia and persistent edema (Holshue et al.,2020; Yavuz \& Unal, 2020). Patients showed clinical improvement with the results of oropharyngeal swabs made on day 8 at the hospital showing negative results even though the nasopharyngeal swab still showed positive results. There were no side effects appear from the administration of remdesivir in these patients (Jacob et al., 2016; Dornemann et al., 2017). Furthermore, treatment of remdesivir was also given to 3 out of 12 COVID-19 patients who were confirmed by the CDC in the United States (McCreary \& Pogue, 2020). Patients receiving this antiviral showed clinical improvement but the patients complained about gastrointestinal disorder and increased aminotransferase, so the efficacy and safety of this drug cannot be confirmed. This is also due to the lack of comparative number of the patients and confounding in therapy including the assessment of the use of remdesivir together with corticosteroids (McCreary \& Pogue, 2020; Yavuz \& Unal, 2020). 
Table 1. Ongoing clinical trials of remdesivir as antiviral for COVID-19 registered in United States National Library of Medicine Clinical Trials

\begin{tabular}{|c|c|c|c|c|c|c|c|}
\hline \multirow[t]{2}{*}{ Clinical trial identifier } & \multirow{2}{*}{$\begin{array}{l}\text { Estimated } \\
\text { enrollment }\end{array}$} & \multirow{2}{*}{$\begin{array}{l}\text { Phase of } \\
\text { the study }\end{array}$} & \multirow{2}{*}{ Condition } & \multicolumn{2}{|c|}{ Intervention } & \multirow{2}{*}{$\begin{array}{l}\text { Primary outcome } \\
\text { measures }\end{array}$} & \multirow{2}{*}{$\begin{array}{l}\text { Recruitment } \\
\text { status }\end{array}$} \\
\hline & & & & Experimental arm & Comparator & & \\
\hline $\begin{array}{l}\text { NCT04292899 } \\
\text { (Gilead Sciences, 2020b) }\end{array}$ & 400 & Phase 3 & Severe COVID-19 & $\begin{array}{l}\text { Arm 1: Remdesivir IV } \\
\text { infusion for } 5 \text { days }+ \\
\text { standardized care } \\
\text { Arm 2: Remdesivir IV } \\
\text { infusion for } 10 \text { days }\end{array}$ & Active: No placebo & $\begin{array}{l}\text { Proportion of participants } \\
\text { with normalization } \\
\text { of fever and oxygen } \\
\text { saturation through day } 14\end{array}$ & $\begin{array}{l}\text { Active, not } \\
\text { recruiting }\end{array}$ \\
\hline $\begin{array}{l}\text { NCT04292730 } \\
\text { (Gilead Sciences, 2020c) }\end{array}$ & 600 & Phase 3 & $\begin{array}{l}\text { Moderate } \\
\text { COVID-19 }\end{array}$ & $\begin{array}{l}\text { Arm 1: Remdesivir IV } \\
\text { infusion for } 5 \text { days }+ \\
\text { standardized care } \\
\text { Arm 2: Remdesivir IV } \\
\text { infusion for } 10 \text { days }\end{array}$ & $\begin{array}{l}\text { Arm 3: Active (stan- } \\
\text { dard of care) }\end{array}$ & $\begin{array}{l}\text { Proportion of participants } \\
\text { discharged by day } 14\end{array}$ & $\begin{array}{l}\text { Active, not } \\
\text { recruiting }\end{array}$ \\
\hline $\begin{array}{l}\text { NCT04252664 } \\
(\text { Cao, 2020a) }\end{array}$ & 308 & Phase 3 & $\begin{array}{l}\text { Mild and Moderate } \\
\text { COVID-19 }\end{array}$ & $\begin{array}{l}\text { Arm 1: Remdesivir IV } \\
\text { for } 10 \text { days }(200 \mathrm{mg} \\
\text { loading dose for day } 1 \\
\text { followed by } 100 \mathrm{mg} \mathrm{IV} \\
\text { for } 9 \text { days })\end{array}$ & $\begin{array}{l}\text { Arm 2: Placebo that } \\
\text { matches remdesivir in } \\
\text { dose and duration }\end{array}$ & $\begin{array}{l}\text { Time to Clinical Recovery } \\
\text { up to } 28 \text { days }\end{array}$ & Suspended \\
\hline $\begin{array}{l}\text { NCT04257656 } \\
(\mathrm{CaO}, 2020 \mathrm{~b})\end{array}$ & 453 & Phase 3 & Severe COVID-19 & $\begin{array}{l}\text { Arm 1: Remdesivir IV } \\
\text { for } 10 \text { days }(200 \mathrm{mg} \\
\text { loading dose for day } 1 \\
\text { followed by } 100 \mathrm{mg} \text { IV } \\
\text { for } 9 \text { days })\end{array}$ & $\begin{array}{l}\text { Arm 2: Placebo that } \\
\text { matches remdesivir in } \\
\text { dose and duration }\end{array}$ & $\begin{array}{l}\text { Time to } \quad \text { Clinical } \\
\text { Improvement } \\
\text { ( } \text { (TTCI) }\end{array}$ & Completed \\
\hline $\begin{array}{l}\text { NCT04280705 } \\
\text { (NIAID, 2020) }\end{array}$ & $394(1: 1)$ & Phase 3 & $\begin{array}{l}\text { Hospitalized } \\
\text { patients with } \\
\text { COVID-19 (no } \\
\text { specific severity) }\end{array}$ & $\begin{array}{l}\text { Arm 1: } 200 \mathrm{mg} \text { RDV } \\
\text { IV for day } 1 \text { followed } \\
\text { by } 100 \mathrm{mg} \text { IV QD for } 9 \\
\text { days }\end{array}$ & $\begin{array}{l}\text { Arm 2: Placebo that } \\
\text { matches remdesivir in } \\
\text { dose and duration }\end{array}$ & $\begin{array}{l}\text { Percentage of subjects } \\
\text { reporting each severity } \\
\text { rating on the } 7 \text {-point } \\
\text { ordinal scale within } 15 \\
\text { days }\end{array}$ & Completed \\
\hline
\end{tabular}




\section{Table 1. Continued}

\begin{tabular}{|c|c|c|c|c|c|c|c|}
\hline \multirow[t]{2}{*}{ Clinical trial identifier } & \multirow{2}{*}{$\begin{array}{l}\text { Estimated } \\
\text { enrollment }\end{array}$} & \multirow{2}{*}{$\begin{array}{l}\text { Phase of } \\
\text { the study }\end{array}$} & \multirow[t]{2}{*}{ Condition } & \multicolumn{2}{|c|}{ Intervention } & \multirow{2}{*}{$\begin{array}{l}\text { Primary outcome } \\
\text { measures }\end{array}$} & \multirow{2}{*}{$\begin{array}{l}\text { Recruitment } \\
\text { status }\end{array}$} \\
\hline & & & & Experimental arm & Comparator & & \\
\hline $\begin{array}{l}\text { NCT04302766 } \\
\text { (US-AMRDC, 2020) }\end{array}$ & $\begin{array}{l}\text { General } \\
\text { (Intermediate } \\
\text { size population) }\end{array}$ & NA & $\begin{array}{l}\text { Any } \\
\text { case }\end{array}$ & Not stated & Not stated & NA & Available \\
\hline $\begin{array}{l}\text { NCT04315948 } \\
\text { (DisCoVeRy trial) } \\
\text { (INSERM, 2020) }\end{array}$ & 3100 & Phase 3 & $\begin{array}{l}\text { COVID-19 in } \\
\text { hospitalized adults }\end{array}$ & $\begin{array}{l}\text { Arm 1: } 200 \mathrm{mg} \text { RDV } \\
\text { IV for day } 1 \text { followed } \\
\text { by } 100 \mathrm{mg} \text { IV QD for } 9 \\
\text { days } \\
\text { Arm 2: Lopinavir/ } \\
\text { ritonavir ( } 400 \mathrm{mg} / 100 \\
\text { mg) tablet BID for } 14 \\
\text { days } \\
\text { Arm 3: Lopinavir/ } \\
\text { ritonavir (400 mg/100 } \\
\text { mg) tablet BID for } 14 \\
\text { days plus interferon b-1a } \\
44 \mathrm{mg} \text { subcutaneously in } \\
\text { total of three doses (day } \\
1,3 \text { and } 6 \text { ) }\end{array}$ & $\begin{array}{l}\text { Arm 4: (active) } \\
\text { standard of care }\end{array}$ & $\begin{array}{l}\text { Percentage of subject } \\
\text { reporting each severity } \\
\text { rating on a } 7 \text {-point ordinal } \\
\text { scale within } 15 \text { days. }\end{array}$ & Recruiting \\
\hline
\end{tabular}


Currently, there are several clinical trials that have evaluated the safety and efficacy of remdesivir for mild to severe COVID-19 cases. According to McCreary, remdesivir has undergone four clinical trials in patients who come from the United States (Table 1). There are also two additional trials from China. These tests are listed in https://clinicaltrials.gov, namely NCT04257656 (severe disease) and NCT04252664 (mild-moderate disease) (McCreary \& Pogue, 2020). Gilead Sciences has conducted 2 randomized phase 3 clinical trials, an open label clinical trial involving 1000 COVID-19 patients. The first trial was carried out on 400 severe COVID-19 patients, in which the patients were divided into two arms. Those in arm 1 were given remdesivir therapy for 5 days while those in arm 2 were given remdesivir for 10 days (Gilead-Sciences, 2020b). On the other hand, the second trial enrolled 600 COVID-19 patients with moderate case severity. The patients have been administered remdesivir with the same dosage regimen as the standard of care and with standard of care alone (control) as a comparator (Gilead-Sciences, 2020c) (Table 1).

Besides the two studies conducted by Gilead Sciences, there are other studies in China and Japan Friendship Hospital (Sisay, 2020). China initiated two randomized, double-blind, placebo-controlled clinical trials aiming to assess the safety and efficacy of remdesivir compared to placebo. The first study involved 308 hospitalized adult patients with mild to moderate COVID-19 cases (Cao, 2020a) (Table 1). The patients were randomized to be able to intervene with remdesivir for 10 days and placebo. The primary end point of this trial is to determine Time to Clinical Recovery (TTCR) within 28 days. Another phase 3 of randomized, double-blind, placebo-controlled trial was conducted to 453 adult patients hospitalized with severe cases of COVID-19. Patients were divided into two arms, remdesivir was given to arm 1 while placebo that had been adjusted with the dose and duration of remdesivir was given to arm 2 . The primary outcome measured in this study was Time to Clinical Improvement (TTCI) examined at day 28 (Cao, $2020 \mathrm{~b}$ ) (Table 1). At the time of this review, a second trial was published by The Lancet, although this trial was not statistically significant. Patients receiving remdesivir therapy showed a faster Time to Clinical Improvement (TTCI) compared to patients who received a placebo with a therapy duration of 10 days or less (Hazard ratio 1.52 [0.95-2.443]). This test also showed that remdesivir did not show any statistically significant clinical benefits (Wang Y.et al., 2020), therefore cohort research in larger numbers is required.

U.S. National Institute of Allergy and Infectious Disease (NIAID) also conducted phase 3 clinical trials in an adaptive randomized, double-blind, placebo-controlled clinical trial. This test was carried out on 394 hospitalized
COVID-19 patients with the aim of assessing the safety and efficacy of remdesivir. In this test, the patients were divided into two arms: arm 1 receiving intervention with remdesivir therapy at a loading dose of $200 \mathrm{mg}$ intravenously on the first day, followed by a dose of $100 \mathrm{mg}$ intravenously for 9 days (total of 10 days therapy) and arm 2 receiving placebo for 10 days. The main indicator in this trial is the percentage of patients who reported severity on the 7-point ordinal scale in 15 days (NIAID, 2020) (Table 1). This clinical trial was also completed with the conclusion that remdesivir is able to shorten the time to recovery in adult patients who were hospitalized with COVID-19 and provided an evidence of lower respiratory tract infection. Median recovery time of COVID-19 patients who were administrated with remdesivir is 11 days as compared with patients who received placebo which is 15 days (Hazard ratio for death , $0.70 ; 95 \%$ CI, 0.47 to 1.04) (Beigel et al., 2020).

Remdesivir is also given as expanded access (compassionate use) using sponsorship and coordination from the U.S Army Medical Research and Development Command (AMRDC) (USAMRDC, 2020) for emergency investigations of new drugs. Gilead Sciences synthesizes and develops this drug therefore it can be used as compassionate use for COVID-19 patients (Coppock, 2020). In a recent observational study, it has been revealed that severe COVID-19 patients treated with compassionate use of remdesivir showed a clinical increase in $68 \%$ of cases (Grein et al., 2020; Ahsan et al., 2020).

A solidarity trial on remdesivir has also been conducted by WHO at global level (Branswell, 2020). The National Institute of Health and Medical Research (INSERM) from France has started the DisCoVery trial (INSERM, 2020). The trial protocol was registered on March 20, 2020 and is available at http://clinicaltrials. gov/ct2/show/NCT04315948. There are 3100 hospitalized adult COVID-19 patients participating in this study. There are four arms, in which remdesivir was provided in the usual dosage regimen in one of the intervention groups (arm 1) while arm 2 received lopinavir/ritonavir (400 mg/100 mg) tablet BID for 14 days, arm 3 received lopinavir/ritonavir (400 mg/100 $\mathrm{mg}$ ) tablet BID for 14 days plus Interferon $\beta$-1a $44 \mathrm{mg}$ subcutaneously in total of three doses (day 1, 3 and 6) and arm 4 received standard of care. The primary objective of this study is to evaluate the clinical efficacy and safety of different investigational therapeutics relative to the control arm in patients hospitalized with COVID-19, while the primary endpoint is the subject clinical status (on a 7-point ordinal scale) within 15 days (Table 1). 


\section{CONCLUSIONS}

Remdesivir is one of the antivirals that has been promoted to treat SARS-CoV-2 virus infection. The mechanism of action of this drug is by interfering with nsp 12 polymerase even when the exoribonuclease proofreading activity is intact. Several clinical trials have been conducted to evaluate the safety and efficacy of remdesivir against COVID-19. There are two completed phase 3 clinical trials and some ongoing clinical trials (Gilead Sciences and DisCoVeRy trial). Based on two clinical trials completed, satisfactory results are shown in patients with remdesivir therapy compared with patients who received placebo, although it is very important to wait for the results of other ongoing clinical trials to strengthen the evidence of the safety and efficacy of this drug.

\section{ACKNOWLEDGMENT}

The authors are grateful to the authorities of the Faculty of Pharmacy, Universitas Airlangga, Surabaya, Indonesia for the facilities.

\section{REFERENCES}

Ahmad, A., Rehman, M. U., Alkharfy, K. M. (2020). An alternative approach to minimize the risk of coronavirus (COVID-19) and similar infections. European Review for Medical and Pharmacological Sciences, 24(7), 40304034.

Ahsan, W., Javed, S., Bratty, M.A., Alhazmi, H.A., \& Najmi, A. (2020). Treatment of SARS-CoV-2: How far have we reached?. Drug Discoveries \& Therapeutics, 14(2), 67-72.

Agostini, M.L., Andres, E.L., Sims, A.C., Graham, R.L., Sheahan, T.P., Lu, X., Smith, E.C., Case, J.B., Feng, J.Y., Jordan, R., Ray, A.S., Cihlar, T., Siegel, D., Mackman, R.L., Clarke, M.O., Baric, R.S., \& Denison, M.R. (2018). Coronavirus susceptibility to the antiviral remdesivir (GS-5734) is mediated by the viral polymerase and the proofreading exoribonuclease. mBio, 9(2), 1-15.

Beigel, J. H., Tomashek, K. M., Dodd, L. E., Mehta, A.K. (2020). Remdesivir for the treatment of COVID-19 - Preliminary report. The New England Journal of Medicine, doi: 10.1056/NEJMoa2007764.

Benvenuto, D., Giovanetti, M., Ciccozzi, A., Spoto, S., Angeletti, S., Ciccozzi, M. (2020). The 2019-new coronavirus epidemic: Evidence for virus evolution. Journal of Medical Virology, 92(4), 455-459.

Branswell, H. (2020). WHO to launch multinational trial to jumpstart search for coronavirus drugs (World Health Organization). Available at: http://www.statnews. com/2020/03/18/who-to-launch-multinational-trial-tojumpstartsearch-for-coronavirus-drugs/. Accessed on 15 July 2020.

Cao, Y. C., Deng, Q. X., Dai, S. X. (2020). Remdesivir for severe acute respiratory syndrome coronavirus 2 causing COVID-19: An evaluation of the evidence. Travel Medicine and Infectious Disease, 35, 101647.

Cao, B. (2020a). Mild/Moderate 2019-nCoV Remdesivir RCT. Available at: https://clinicaltrials.gov/ct2/show/ NCT04252664. Accessed on 15 July 2020.

Cao, B. (2020b). Severe 2019-nCoV Remdesivir RCT. Available at: http://clinicaltrials.gov/ct2/show/ NCT04257656. Accessed on 15 July 2020.

Coppock, K. (2020). FDA announces two drugs approved for 'Compassionate Use' in treating COVID-19. (Pharmacy Times). Available at: https://www. pharmacytimes.com/news/fda-announces-two-drugsapproved-forcompassionate-use-in-treating-covid-19. Accessed on 15 July 2020.

Dornemann, J., Burzio, C., Ronsse, A., Sprecher, A., Clerck, H.D., Herp, M.V., Kolie, M.C., Yosifiva, V., Caluwaerts, S., McElroy, A.K., \& Antierens, A. (2017). First newborn baby to receive experimental therapies survives ebola virus disease. The Journal of Infectious Diseases, 215(2), 171-174.

Gilead Sciences. (2020a). Gilead sciences update on the company's ongoing response to COVID-19. (GILEAD). Available at: https://www.gilead.com/purpose/ advancing-global-health/covid-19. Accessed on 15 July 2020.

Gilead Sciences. (2020b). Study to evaluate the safety and antiviral activity of remdesivir (GS-5734TM) in participants with severe coronavirus disease (COVID-19). Available at: https://clinicaltrials.gov/ct2/ show/NCT04292899. Accessed on 15 July 2020.

Gilead Sciences. (2020c). Study to evaluate the safety and antiviral activity of remdesivir (GS-5734TM) in participants with moderate coronavirus disease (COVID-19) compared to standard of care treatment. Available at: https://clinicaltrials.gov/ct2/show/ NCT04292730. Accessed on 15 July 2020.

Gordon, C. J., Tchesnokov, E. P., Feng, J. Y., Porter, D. P., Gotte, M. (2020). The antiviral compound remdesivir potently inhibits RNA-dependent RNA polymerase from middle east respiratory syndrome coronavirus. The 
Journal of Biological Chemistry, 295(15), 4773-4779.

Grein, J., Ohmagari, N., Shin, D., Diaz, G., Asperges, E., Castagna, A., et al. (2020). Compassionate use of remdesivir for patients with severe COVID-19. The New England Journal of Medicine, 382, 2327-36.

Holshue, M.L., De, B.C., Lindquist, S., Lofy, K.H., Wiesman, J., Bruce, H., Spitters, C., Ericson, K., Wilkerson, S., Tural, A., Diaz, G., Cohn, A., Fox, L., Patel, A., Gerber, SI., Kim, L., Tong, S., Lu, X., Lindstrom, S., Pallansch, M.A., Weldon, W.C., Biggs, H.M., Uyeki, T.M., \& Pillai, S.K. (2020). First case of 2019 novel coronavirus in the United States. The New England Journal of Medicine, 382, 929-936.

INSERM. (2020). Trial of treatments for COVID-19 in hospitalized adults (DisCoVeRy). Available at: https:// clinicaltrials.gov/ct2/show/NCT04315948. Accessed on 15 July 2020.

Jacobs, M., Rodger, A., Bell, D.J., Bhagani, S., Cropley, I., Filipe, A., Gifford, R.J., Hopkins, S., Hughes, J., Jabeen, F., Johannessen, I., Karageorgopoulos, D., Lackenby, A., Lester, R., Liu, RSN., MacConnachie, A., Mahungu, T., Martin, D., Marshall, N., Mepham, S., Orton, R., Palmarini, M., Patel, M., Perry, C., Peters, SE., Porter, D., Ritchie, D., Ritchie, N.D., Seaton, R.A., Sreenu, V.B., Templeton, K., Warren, S., Wilkie, G.S., Zambon, M., Gopal, R., \& Thomson, E.C. (2016). Late ebola virus relapse causing meningoencephalitis: A case report. The Lancet, 388(10043), 498-503.

Kakodkar, P., Kaka, N., Baig, M. N. (2020). A Comprehensive Literature Review on the Clinical Presentation, and Management of the Pandemic Coronavirus Disease 2019 (COVID-19). Cureus, 12(4), $1-18$.

Li, Z., Wang, X., Cao, D., Sun, R., Li, C., \& Li, G. (2020). Rapid review for the anti-coronavirus effect of remdesivir. Drug Discoveries \& Therapeutics, 14(2), 7376.

Lo, M.K., Friederike, F., Gary, J.M., Jordan, R., Bannister, R., Cronin, J., Patel, N.R., Klena, J.D., Nichol, S.T., Cihlar, T., Zaki, S.R., Feldmann, H., Spiropoulou, C.F., \& Wit, E.D. (2019). Remdesivir (GS-5734) protects African green monkeys from nipah virus challenge. Science Translational Medicine, 11, 1-7.

McCreary, E. K., Pogue, J. M. (2020). Coronavirus Disease 2019 Treatment: A Review of Early and Emerging Options. Open Forum Infectious Diseases, 7(4), 1-11.
Mulangu, S., Dodd, L.E., Davey, R.T., Mbaya, O.T., Proschan, M., Mukadi, D., Manzo, M.L., Nzolo, D., Oloma, A.T., Ibanda, A., Ali, R., Coulibaly, S., Levine, A.C., Grais, R., Diaz, J., Lane, H.C., Tamfum, J.J.M., \& PALM Writing Group, for the PALM Consortium Study Team. (2019). A randomized, controlled trial of ebola virus disease therapeutics. The New England Journal of Medicine, 381(24), 2293-2303.

NIAID. (2020). Adaptive COVID-19 Treatment Trial. Available at: https://clinicaltrials.gov/ct2/show/ NCT04280705. Accessed on 15 July 2020.

Sheahan, T.P., Sims, A.C., Graham, R.L., Menachery, V.D., Gralinski, L.E., Case, J.B., Leist, S.R., Pyrc, K., Feng, J.Y., Trantcheva, I., Bannister, R., Park, Y., Babusis, D., Clarke, M.O., Mackman, R.L., Spahn, J.E., Palmiotti, C.A., Siegel, D., Ray, A.S., Cihlar, T., Jordan, R., Denison, M.R., \& Baric, R.S. (2017). Broadspectrum antiviral GS-5734 inhibits both epidemic and zoonotic coronaviruses. Science Translational Medicine, 9, 1-10.

Sheahan, T.P., Sims, A.C., Leist, S.R., Schafer, A., Won, J., Brown, A.J., Montgomery, S.A., Hogg, A., Babusis, D., Clarke, M.O., Spahn, J.E., Bauer, L., Sellers, S., Porter, D., Feng, J.Y., Cihlar, T., Jordan, R., Denison, MR., \& Baric, R.S. (2020). Comparative therapeutic efficacy of remdesivir and combination lopinavir, ritonavir, and interferon beta against MERS-CoV. Nature Communications, 11(1), 1-14.

Sisay, M. (2020). Available evidence and ongoing clinical trials of remdesivir: Could it be a promising therapeutic option for COVID-19. Frontiers in Pharmacology, 11, 791.

Song, W., Gui, M., Wang, X., Xiang, Y. (2018). Cryo-EM structure of the SARS coronavirus spike glycoprotein in complex with its host cell receptor ACE2. PLOS Pathogens, 14(8), 1-19.

US-AMRDC. (2020). Expanded Access Remdesivir (RDV; GS-5734TM). Available at: https://clinicaltrials. gov/ct2/show/NCT04302766. Accessed on 5 April 2020.

Wang, M., Cao, R., Zhang, L., Yang, X., Liu, J., Xu, M., Shi, Z., Hu, Z., Zhong, W., \& Xiao, G. (2020). Remdesivir and chloroquine effectively inhibit the recently emerged novel coronavirus (2019-nCoV) in vitro. Cell Research, 30(3), 269-271.

Wang, Y., Zhang, D., Du, G., Du, R., Zhao, J., Jin, Y., Fu, S., Gao, L., Cheng, Z., Lu, Q., Hu, Y., Luo, G., Wang, K., Lu, Y., Li, H., Wang, S., Ruan, S., Yang, C., Mei, C., 
Wang, Y., Ding, D., Wu, F., Tang, X., Ye, X., Ye, Y., Liu, B., Yang, J., Yin, W., Wang, A., Fan, G., Zhou, F., Liu, Z., Gu, X., Xu, J., Shang, L., Zhang, Y., Cao, L., Guo, T., Wan, Y., Qin, H., Jiang, Y., Jaki, T., Hayden, FG., Horby, PW., Cao, B., \& Wang, C. (2020). . Remdesivir in adults with severe COVID-19: A randomised, doubleblind, placebo-controlled, multicentre trial. The Lancet, 395(10236), 1569-1578.

Warren, T., Jordan, R., Lo, M., Soloveva, V., Ray, A., Bannister, R., Mackman, R., Perron, M., Stray, K., Feng, J., Xu, Y., Wells, J., Stuthman, K., Welch, L., Doerffler, E., Zhang, L., Chun, K., Hui, H., Neville, S., Lew, W., Park, Y., Babusis, D., Strickley, R., Wong, P., Swaminathan, S., Lee, W., Mayers, D., Cihlar, T., \& Bavari, S. (2015). Nucleotide prodrug GS-5734 is a broad-spectrum filovirus inhibitor that provides complete therapeutic protection against the development of Ebola Virus Disease (EVD) in infected non-human primates. In Open Forum Infectious Diseases (Vol. 2, No. suppl_1, pp. LB-2). Infectious Diseases Society of America.

WHO. (2020). World Health Organization situation report. Available at: https:/www.who.int/docs/defaultsource/coronaviruse/situation-reports/20200316-sitrep56-covid-19.pdf?sfvrsn $=9$ fda $7 \mathrm{db} 2$ 2. Accessed on 20 March 2020.
Xu, J., Zhao, S., Teng, T., Abdalla, A. E., Zhu, W., Xie, L., et al. (2020). Systematic Comparison of Two Animal-to-Human Transmitted Human Coronaviruses: SARS-CoV-2 and SARS-CoV. Viruses, 12(2), 244.

Xu, X., Chen, P., Wang, J., Feng, J., Zhou, H., Li, X., Zhong, W., \& Hao, P. (2020). Evolution of the novel coronavirus from the ongoing Wuhan outbreak and modeling of its spike protein for risk of human transmission. Science China Life Sciences, 63(3), 457460 .

Xu, Z., Shi, L., Wang, Y., Zhang, J., Huang, L., Zhang, C., Liu, S., Zhao, P., Liu, H., Zhu, L., Tai, Y., Bai, C., Gao, T., Song, J., Xia, P., Dong, J., \& Zhao, J. (2020). Pathological findings of COVID-19 associated with acute respiratory distress syndrome. The Lancet Respiratory Medicine, 8(4), 420-422.

Yavuz, S. S., Unal, S. (2020). Antiviral treatment of COVID-19. Turkish Journal of Medical Sciences, 50(SI1), 611-619.

Zhang, L., Zhou, R. (2020). Binding mechanism of remdesivir to SARS-CoV-2 RNA dependent RNA polymerase. Preprints, 2020030267, doi: 10.20944/ preprints202003.0267.v1. 